\title{
Antimicrobial Activity of a Lipidated Temporin L Analogue against Carbapenemase-Producing Klebsiella pneumoniae Clinical Isolates
}

\author{
Emanuela Roscetto ${ }^{1,+}{ }^{,}$, Rosa Bellavita ${ }^{2,+}$, Rossella Paolillo ${ }^{1}$, Francesco Merlino ${ }^{2} \mathbb{D}$, Nicola Molfetta ${ }^{2}$, \\ Paolo Grieco ${ }^{2}$, Elisabetta Buommino $2, \ddagger(\mathbb{D}$ and Maria Rosaria Catania $1, *, \ddagger$ (D)
}

check for

updates

Citation: Roscetto, E.; Bellavita, R.; Paolillo, R.; Merlino, F.; Molfetta, N.; Grieco, P.; Buommino, E.; Catania, M.R. Antimicrobial Activity of a Lipidated Temporin L Analogue against Carbapenemase-Producing Klebsiella pneumoniae Clinical Isolates. Antibiotics 2021, 10, 1312.

https://doi.org/10.3390/

antibiotics 10111312

Academic Editor: Francesca Andreoni

Received: 11 October 2021

Accepted: 26 October 2021

Published: 28 October 2021

Publisher's Note: MDPI stays neutral with regard to jurisdictional claims in published maps and institutional affiliations.
1 Department of Molecular Medicine and Medical Biotechnology, University of Naples Federico II, Via S. Pansini 5, 80131 Naples, Italy; emanuela.roscetto@unina.it (E.R.); rossella.paolillo@unina.it (R.P.)

2 Department of Pharmacy, University of Naples Federico II, Via Montesano 49, 80131 Naples, Italy; rosa.bellavita@unina.it (R.B.); francesco.merlino@unina.it (F.M.); nicolamolfetta31@gmail.com (N.M.); paolo.grieco@unina.it (P.G.); elisabetta.buommino@unina.it (E.B.)

* Correspondence: mariarosaria.catania@unina.it; Tel.: +39-081-7464577

$\dagger$ These authors contributed equally to this work.

$\ddagger \quad$ These authors contributed equally to this work.

\begin{abstract}
Over the years, the increasing acquisition of antibiotic resistance genes has led to the emergence of highly resistant bacterial strains and the loss of standard antibiotics' efficacy, including $\beta$-lactam/ $\beta$-lactamase inhibitor combinations and the last line carbapenems. Klebsiella pneumoniae is considered one of the major exponents of a group of multidrug-resistant ESKAPE pathogens responsible for serious healthcare-associated infections. In this study, we proved the antimicrobial activity of two analogues of Temporin L against twenty carbapenemase-producing K. pneumoniae clinical isolates. According to the antibiotic susceptibility assay, all the K. pneumoniae strains were resistant to at least one other class of antibiotics, in addition to beta-lactams. Peptides $\mathbf{1 B}$ and C showed activity on all test strains, but the lipidated analogue $\mathbf{C}$ expressed the greater antimicrobial properties, with MIC values ranging from 6.25 to $25 \mu \mathrm{M}$. Furthermore, the peptide $\mathrm{C}$ showed bactericidal activity at MIC values. The results clearly highlight the great potential of antimicrobial peptides both as a new treatment option for difficult-to-treat infections and as a new strategy of drug-resistance control.
\end{abstract}

Keywords: Klebsiella pneumoniae; ESKAPE; multidrug resistance; carbapenemases; healthcareassociated infections; antimicrobial peptides; Temporin L

\section{Introduction}

In the order Enterobacteriales, Klebsiella pneumoniae is one of the most important causes of bloodstream, urinary and respiratory tract infections in vulnerable hosts [1]. An empirical antibiotic treatment is often required due to the severity of the infections and/or the patient's critical conditions and the use of broad-spectrum antibiotics is necessary because of the possibility of a multidrug-resistant bacteria aetiology.

The worldwide spread of difficult-to-treat extended-spectrum beta-lactamase-producing enterobacteria has led to the use of carbapenems in empirical therapy [2], but the treatment with carbapenems has led to the rapid selection of carbapenem-resistant Enterobacteriales (CRE) [3].

Enterobacteriales may have different mechanisms of resistance to carbapenems. The most widespread one is the production of beta-lactamases with high affinity for carbapenems (carbapenemases). Another common mechanism of resistance is the hyperproduction of $\beta$-lactamases with limited affinity and/or hydrolytic activity toward carbapenems combined with structural alterations such as porin loss [4]. 
Carbapenemase production is also the most epidemiologically relevant resistance mechanism, as the genes for carbapenemases are carried by plasmids and therefore horizontally transmissible [5].

Klebsiella pneumoniae is the most common species harbouring transmissible carbapenemase [6]. In the Ambler classification system, carbapenemases are distributed in three classes depending on their chemical structure: classes A and D include serinecarbapenemases, whereas class B includes metallo-beta-lactamases [7]. Klebsiella pneumoniae carbapenemases (KPCs) are the most common transmissible genes among Enterobacteriales [8].

Treatment options for CRE are aminoglycosides, polymyxins or tigecycline, but some of these drugs have non-negligible adverse effects. Furthermore, many enterobacteria have additional plasmid-borne resistance genes, consequently resulting in resistance to several other antimicrobial groups. This issue induces clinicians to administer a combination therapy of two or more drugs [9]. The threat posed by CRE to human health is evidenced by their placement by WHO in the most critical group of multidrug-resistant bacteria for which the development of new antibiotics is urgently needed [10]. The new therapeutic options against CRE are drugs belonging to already known classes of antibiotics or new beta-lactam/beta-lactamase inhibitor combinations [11].

Antimicrobial peptides (AMPs) could provide a valid chance to overcome and control the antibiotic resistance [12]. Among these compounds, the temporins, isolated from the skin of Rana temporaria [13], represent one of the largest AMPs families. Temporin L (TL) is the most studied isoform for its potent activity both against Gram-positive and Gram-negative bacteria and yeasts. Due to its high cytotoxicity, TL has been the subject of different structure-activity relationship (SAR) studies to obtain novel analogues with an improved therapeutic index [14-16]. In this context, a previous SAR study consisting of the application of lipidation strategy on a potent Temporin $\mathrm{L}$ analogue, named peptide 1B $[17,18]$, has led to the discovery of the lipidated peptide $C$ featured by an alkyl chain of five carbons in para position of Phe $^{1}$ in its N-terminus [19]. The addition of fatty acid conferred to peptide $C$ self-assembling properties improved the effectiveness in inhibiting the growth of both Staphylococcus aureus (ATCC 25923) and Klebsiella pneumoniae (ATCC BAA-1705) cells, with a minimum inhibitory concentration (MIC) of $6.25 \mu \mathrm{M}$. Interestingly, it did not show a significant cytotoxic effect even at the high concentration of $25 \mu \mathrm{M}$ [19]. In this study, we evaluated the activity of peptides $1 B$ and $C$ towards clinical carbapenemresistant K. pneumoniae isolates harboring kpc or metallo-beta-lactamase genes.

The conventional antibiotic susceptibility was tested for the following antibiotics: amoxicillin/clavulanic acid, cefotaxime, ceftazidime, piperacillin/tazobactam, gentamicin, amikacin, trimethoprim-sulfamethoxazole, ciprofloxacin, meropenem, ertapenem and ceftazidime/avibactam. The clinical strains were classified in different category S/I/R (susceptible/intermediate/resistant) according to EUCAST 2021 breakpoints (https: //www.eucast.org/clinical_breakpoints, accessed on 28 April 2021). Table 2 shows the antimicrobial susceptibility profile of clinical strains: except for KNKp, all the isolates were resistant to amoxicillin/clavulanic acid, ceftazidime, cefotaxime, piperacillin/tazobactam and to the carbapenems ertapenem and meropenem (except for KPCKp6 and KPCKp10 that showed an intermediate resistance to meropenem). They were also resistant to ciprofloxacin, excluding KPCKp5 and NDMKp2. Particularly, KPCKp 8 and KPCKp15 showed a resistant profile towards all tested antibiotics. We observed that the aminoglycosides amikacin and gentamicin and the combination ceftazidime/avibactam were the most effective compounds, acting against 52.2\% (12/23), 56.5\% (13/23), 8.7\% (2/23) of clinical strains, respectively. The 22 carbapenem-resistant strains were subjected to molecular tests (Xpert Carba-R-test), which allow the identification of the resistance determinants involved (KPC, VIM, IPM-1, NDM, OXA-48). We found that $81.8 \%$ of the strains (named KPCKp1-KPCKp18) produced KPC-type carbapenemases, whereas $18.2 \%$ produced VIM $(\mathrm{VIM} K p)$ or NDM (NDMKp1, NDMKp2, NDMKp3) metallo-beta-lactamases (MBL). Overall, 
99\% of the K. pneumoniae clinical isolates were multidrug-resistant (MDR, resistant to at least three antibiotics belonging to different antibiotics categories).

\section{Results}

\subsection{Antibiotic Susceptibility and RAPD Profiles}

Twenty-three K. pneumoniae clinical strains were tested in this study and their sources are listed in Table 1. The KPCKp1-KPCKp18 and KNKp strains all come from the Intensive Care Unit (ICU), whereas the strains VIMKp, NDMKp1, NDMKp2 and NDMKp3 come from different wards.

Table 1. K. pneumonaie clinical strains used in antimicrobial assays.

\begin{tabular}{|c|c|c|c|}
\hline Strain Name & Source & Strain Name & Source \\
\hline $\mathrm{KNK} p$ & $\mathrm{AF}$ & KРCKp12 & TR \\
\hline КРCKp 1 & $\mathrm{TR}$ & КРСКp 13 & $\mathrm{E}$ \\
\hline KРCKp2 & TFr & КРCКр14 & $\mathrm{B}$ \\
\hline КРСKp3 & UC & КРСKp 15 & $\mathrm{TF}$ \\
\hline КРСKp 4 & UC & КРCKp16 & TR \\
\hline КРСKp5 & $\mathrm{AF}$ & КРСКр17 & $\mathrm{U}$ \\
\hline КРСКр6 & $\mathrm{U}$ & КРСК 18 & $\mathrm{U}$ \\
\hline КРСKp7 & $\mathrm{E}$ & & \\
\hline КРСKp 8 & $\mathrm{TF}$ & VIMKp & $\mathrm{AF}$ \\
\hline КРCKp 9 & $\mathrm{C}$ & NDM $K p 1$ & Tfr \\
\hline KPCKp 10 & $\mathrm{E}$ & NDM $K p 2$ & $\mathrm{U}$ \\
\hline КРСКp 11 & $\mathrm{P}$ & NDMK $p 3$ & E \\
\hline
\end{tabular}

Abbreviations: $\mathrm{AF}$, pharyngeal aspirate; $\mathrm{B}$, bronchus aspirate; $\mathrm{C}$, catheter; $\mathrm{CF}$, cystic fibrosis; $\mathrm{E}$, blood colture; $\mathrm{P}$ prothesis; TF, pharyngeal swab; $\mathrm{TFr}$, wound swab; TR, rectal swab; UC, catheter urine; $\mathrm{U}$, urine.

Table 2. Antibiotic-susceptibility profile of K. pneumoniae clinical strains.

\begin{tabular}{|c|c|c|c|c|c|c|c|c|c|c|c|}
\hline Strains & AMC & CTX & CAZ & TZP & GM & AK & SXT & CIP & MEM & ERT & CAZ/AVI \\
\hline $\mathrm{KNK} p$ & $4(S)$ & $\leq 1(S)$ & $\leq 0.5(\mathrm{~S})$ & $\leq 4(\mathrm{~S})$ & $\leq 1(\mathrm{~S})$ & $\leq 4(\mathrm{~S})$ & $\leq 1(S)$ & $\leq 0.25$ (S) & $\leq 0.125(S)$ & $\leq 0.25$ (S) & $1(S)$ \\
\hline КРСKp 1 & $>16(\mathrm{R})$ & $>32(\mathrm{R})$ & $>32(\mathrm{R})$ & $>64(\mathrm{R})$ & $\leq 1(\mathrm{~S})$ & $\leq 1(\mathrm{~S})$ & $4(\mathrm{I})$ & $>2(\mathrm{R})$ & $>8(\mathrm{R})$ & $>4(\mathrm{R})$ & $8(S)$ \\
\hline КРCKp2 & $>16(\mathrm{R})$ & $>32(\mathrm{R})$ & $>32(\mathrm{R})$ & $>64(\mathrm{R})$ & $\leq 1(\mathrm{~S})$ & $\leq 1(\mathrm{~S})$ & $4(\mathrm{I})$ & $>2(\mathrm{R})$ & $>8(\mathrm{R})$ & $>4(\mathrm{R})$ & $1(\mathrm{~S})$ \\
\hline КРСKp3 & $>32(\mathrm{R})$ & $>4(\mathrm{R})$ & $>8(\mathrm{R})$ & $>16(\mathrm{R})$ & $\leq 1(\mathrm{~S})$ & $4(S)$ & $>4(\mathrm{R})$ & $>1(\mathrm{R})$ & $>8(\mathrm{R})$ & $>1(\mathrm{R})$ & $4(S)$ \\
\hline КРСKp 4 & $>32(\mathrm{R})$ & $>4(\mathrm{R})$ & $>8$ (R) & $>16(\mathrm{R})$ & $>4(\mathrm{R})$ & $4(S)$ & $>4(\mathrm{R})$ & $>1$ (R) & $>8(\mathrm{R})$ & $>1(\mathrm{R})$ & $1(S)$ \\
\hline КРСКp5 & $>16(\mathrm{R})$ & $>32(\mathrm{R})$ & $>32(\mathrm{R})$ & $>64(\mathrm{R})$ & $>8$ (R) & $4(S)$ & $>8$ (R) & $0.25(\mathrm{~S})$ & $>8(\mathrm{R})$ & $>4(\mathrm{R})$ & $4(S)$ \\
\hline КРСКp6 & $>32(\mathrm{R})$ & $>4(\mathrm{R})$ & $>32(\mathrm{R})$ & $>64(\mathrm{R})$ & $2(S)$ & $8(S)$ & $>4(\mathrm{R})$ & $>1(\mathrm{R})$ & 8 (I) & $>1(\mathrm{R})$ & $1(S)$ \\
\hline КРСKp 7 & $>32(\mathrm{R})$ & $>4(\mathrm{R})$ & $>8$ (R) & $>16(\mathrm{R})$ & 4 (I) & $\leq 4(\mathrm{~S})$ & $\leq 1(S)$ & $>1(\mathrm{R})$ & $>8(\mathrm{R})$ & $>1(\mathrm{R})$ & $1(\mathrm{~S})$ \\
\hline КРСКp 8 & $>16(\mathrm{R})$ & $>32(\mathrm{R})$ & $>32(\mathrm{R})$ & $>64(\mathrm{R})$ & $>8(\mathrm{R})$ & $32(\mathrm{R})$ & $>8(\mathrm{R})$ & $>2(\mathrm{R})$ & $>8(\mathrm{R})$ & $>4(\mathrm{R})$ & $>8(\mathrm{R})$ \\
\hline КРСКp 9 & $>16(\mathrm{R})$ & $>32(\mathrm{R})$ & $>32(\mathrm{R})$ & $>64(\mathrm{R})$ & $\leq 1(S)$ & $4(S)$ & $>8(\mathrm{R})$ & $>2(\mathrm{R})$ & $>8(\mathrm{R})$ & $>4(\mathrm{R})$ & $4(S)$ \\
\hline КРСКp10 & $>16(\mathrm{R})$ & $>32(\mathrm{R})$ & $>32(\mathrm{R})$ & $>64(\mathrm{R})$ & $\leq 1(\mathrm{~S})$ & $\leq 1(\mathrm{~S})$ & $>8(\mathrm{R})$ & $>2(\mathrm{R})$ & 8 (I) & $>4(\mathrm{R})$ & $4(S)$ \\
\hline КРСКp11 & $>32(\mathrm{R})$ & $>4(\mathrm{R})$ & $>8(\mathrm{R})$ & $>16(\mathrm{R})$ & $>4(\mathrm{R})$ & $>16(\mathrm{R})$ & $>8(\mathrm{R})$ & $>1(\mathrm{R})$ & $>8(\mathrm{R})$ & $>1(\mathrm{R})$ & $1(S)$ \\
\hline КРСКp 12 & $>16(\mathrm{R})$ & $>32(\mathrm{R})$ & $>32(\mathrm{R})$ & $>64(\mathrm{R})$ & $2(S)$ & $>32(\mathrm{R})$ & $\leq 1(S)$ & $>2(\mathrm{R})$ & $>8(\mathrm{R})$ & $>4(\mathrm{R})$ & $4(S)$ \\
\hline КРСКр13 & $>16(\mathrm{R})$ & $>32(\mathrm{R})$ & $>32(\mathrm{R})$ & $>64(\mathrm{R})$ & $>8(\mathrm{R})$ & $>16(\mathrm{R})$ & $>8(\mathrm{R})$ & $>2(\mathrm{R})$ & $>8(\mathrm{R})$ & $>4(\mathrm{R})$ & $4(S)$ \\
\hline КРСКp14 & $>16(\mathrm{R})$ & $>32(\mathrm{R})$ & $>16(\mathrm{R})$ & $>64(\mathrm{R})$ & $>8(\mathrm{R})$ & $32(\mathrm{R})$ & $>8(\mathrm{R})$ & $>2(\mathrm{R})$ & $>8(\mathrm{R})$ & $>4(\mathrm{R})$ & $1(S)$ \\
\hline КРСКp15 & $>16(\mathrm{R})$ & $>32(\mathrm{R})$ & $>32$ (R) & $>64(\mathrm{R})$ & $>8(\mathrm{R})$ & $32(\mathrm{R})$ & $>8(\mathrm{R})$ & $>2(\mathrm{R})$ & $>8(\mathrm{R})$ & $>1(\mathrm{R})$ & $>8(\mathrm{R})$ \\
\hline КРCKp16 & $>16(\mathrm{R})$ & $>32(\mathrm{R})$ & $>32(\mathrm{R})$ & $>64(\mathrm{R})$ & $2(S)$ & $4(S)$ & $>8(\mathrm{R})$ & $>2(\mathrm{R})$ & $>8(\mathrm{R})$ & $>4(\mathrm{R})$ & $4(S)$ \\
\hline КРСКp17 & $>16(\mathrm{R})$ & $>32(\mathrm{R})$ & $>32(\mathrm{R})$ & $>64(\mathrm{R})$ & $\leq 1(S)$ & $\leq 1(\mathrm{~S})$ & $\leq 1(\mathrm{~S})$ & $>2(\mathrm{R})$ & $>8(\mathrm{R})$ & $>4(\mathrm{R})$ & $4(S)$ \\
\hline КРСКp18 & $>32(\mathrm{R})$ & $>4(\mathrm{R})$ & $>8(\mathrm{R})$ & $>16(\mathrm{R})$ & $2(S)$ & $4(S)$ & $\leq 1(\mathrm{~S})$ & $>1(\mathrm{R})$ & $>8(\mathrm{R})$ & $>1(\mathrm{R})$ & $4(S)$ \\
\hline
\end{tabular}


Table 2. Cont.

\begin{tabular}{lccccccccccc}
\hline Strains & AMC & CTX & CAZ & TZP & GM & AK & SXT & CIP & MEM & ERT & CAZ/AVI \\
\hline VIMKp & $>32(\mathrm{R})$ & $>4(\mathrm{R})$ & $>8(\mathrm{R})$ & $>16(\mathrm{R})$ & $2(\mathrm{~S})$ & $\leq 4(\mathrm{I})$ & $>4(\mathrm{R})$ & $1(\mathrm{R})$ & $8(\mathrm{R})$ & $>1(\mathrm{R})$ & $>8(\mathrm{R})$ \\
\hline NDMKp1 & $>16(\mathrm{R})$ & $>32(\mathrm{R})$ & $>32(\mathrm{R})$ & $>64(\mathrm{R})$ & $>8(\mathrm{R})$ & $16(\mathrm{I})$ & $\leq 1(\mathrm{~S})$ & $>2(\mathrm{R})$ & $8(\mathrm{R})$ & $>1(\mathrm{R})$ & $>8(\mathrm{R})$ \\
\hline NDMKp2 & $>16(\mathrm{R})$ & $32(\mathrm{R})$ & $>32(\mathrm{R})$ & $>64(\mathrm{R})$ & $>8(\mathrm{R})$ & $>16(\mathrm{R})$ & $>8(\mathrm{R})$ & $\begin{array}{c}\leq 0.06 \\
(\mathrm{~S})\end{array}$ & $>8(\mathrm{R})$ & $>4(\mathrm{R})$ & $>8(\mathrm{R})$ \\
\hline NDMKp3 & $>16(\mathrm{R})$ & $>32(\mathrm{R})$ & $>32(\mathrm{R})$ & $>64(\mathrm{R})$ & $>8(\mathrm{R})$ & $32(\mathrm{R})$ & $\leq 1(\mathrm{~S})$ & $>2(\mathrm{R})$ & $>8(\mathrm{R})$ & $>1(\mathrm{R})$ & $>8(\mathrm{R})$ \\
\hline
\end{tabular}

Abbreviations: AMC, Amoxicillin/clavulanic acid; AK, Amikacin; CAZ, Ceftazidime; CAZ/AVI, Ceftazidime/avibactam; CIP Ciprofloxacin; CTX, Cefotaxime; ERT, Ertapenem; GM, Gentamicin; I, Intermediate; MEM, Meropenem; R, Resistant; S, Susceptible; SXT, Trimethoprim-Sulfamethoxazole; TZP, Piperacillin/tazobactam.

All the K. pneumoniae clinical strains coming from the same ward (ICU) (KPCKp1KPCKp18) were genotyped through the Random Amplified Polymorphic DNA (RAPD) analysis based on the Polymerase Chain Reaction technique (PCR), and the genomic profiles were compared with the antibiotic susceptibility patterns. As shown in Figure 1, the strains showed intra-specific variations between the genomic profiles, except for KPCKp 1 and KPCKp2, sharing the same antibiotic susceptibility profile (Table 2), as well as KPCKp13 and KPCK 14 . KPCKp 5 showed a genetic profile comparable to that of KPCKp1 and KPCKp2, but a different susceptibility to GM, SXT and CIP. Similarly, KPCKp11 and KPCKp12 showed a comparable genetic profile, but differences in sensitivity to GM and SXT. Regarding the strains KPCKp15 and KPCKp16, RAPD analysis showed some similarity, but by comparing their antibiotic susceptibility profile we found that these were different. KPCKp 15 showed resistance to GM, AK and CAZ/AVI, whereas KPCKp16 did not. On the contrary, KPCKp17 and KPCKp 18 showed a similar profile for antibiotic susceptibility, but a different RAPD profile. Thus, from the results of RAPD analysis, we chose to work only on 21 KPCKp strains that showed both different genetic and antibiotic susceptibility profiles, excluding the strains KPCKp 2 and KPCKp14. The strains selected were further investigated.

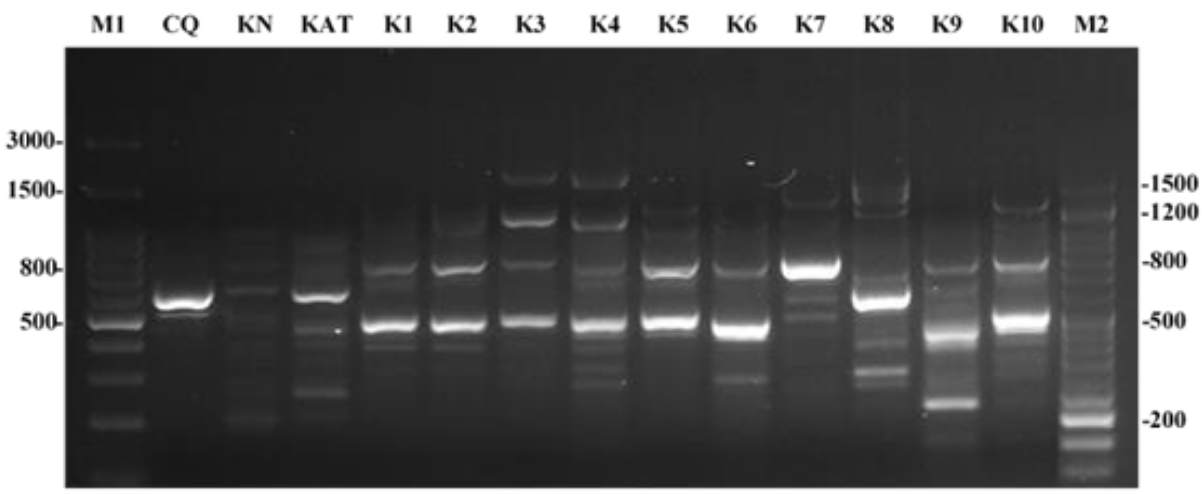

$\begin{array}{llllllllllllll}\text { M1 } & \text { CQ } & \text { KN } & \text { KAT } & \text { K11 } & \text { K12 } & \text { K13 } & \text { K14 } & \text { K15 } & \text { K16 } & \text { K17 } & \text { K18 } & \text { M2 }\end{array}$

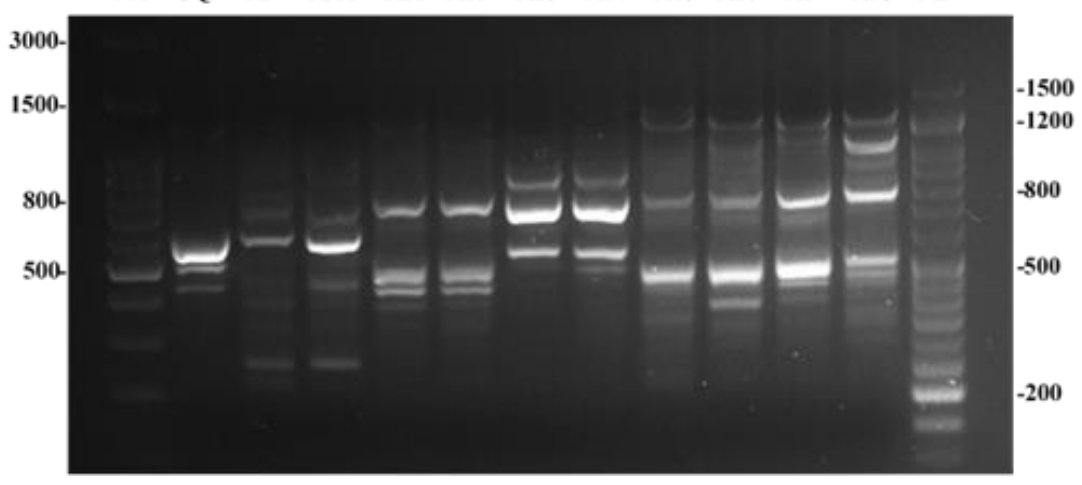

Figure 1. RAPD analysis of both ATCC and clinical strains from ICU. M1: $100 \mathrm{bp}$ ladder; M2: $50 \mathrm{bp}$. 


\subsection{Antimicrobial Activity of Peptides}

The antimicrobial activity of peptides 1B and C was tested against ATCC 13883 (KCQ) and ATCC BAA-1705 (KAT) as K. pneumoniae reference strains and K. pneumoniae clinical isolates. The peptides resulted to be active against all the tested strains and MIC values are reported in Table 3. Both peptides inhibited the growth of carbapenem-sensitive strains (KCQ and KNKp) at MIC values of $6.25 \mu \mathrm{M}$; on the other hand, both peptides were able to effectively inhibit the growth of carbapenemase-producing strains with MIC values ranging from $12.5 \mu \mathrm{M}$ to $100 \mu \mathrm{M}$ for peptide $\mathbf{1 B}$, and MIC values ranging from $6.25 \mu \mathrm{M}$ to $25 \mu \mathrm{M}$ for peptide $\mathrm{C}$. Furthermore, peptide $\mathrm{C}$ showed bactericidal activity at MIC values, whereas 1B was bacteriostatic at MIC values, and bactericidal at $2 \times$ MIC values.

Table 3. Minimum inhibitory concentrations (MIC) of peptides 1B and C against K. pneumoniae test strains.

\begin{tabular}{|c|c|c|c|}
\hline \multirow{2}{*}{ Strains } & \multicolumn{2}{|c|}{$\operatorname{MIC}(\mu \mathrm{M})$} & \multirow{2}{*}{$\begin{array}{l}\text { MIC }(\mu \mathrm{g} / \mathrm{mL}) \\
\text { Polymyxin E }\end{array}$} \\
\hline & 1B & $\mathrm{C}$ & \\
\hline KCQ & 6.25 & 6.25 & $<2(S)$ \\
\hline KAT & 12.5 & 6.25 & $<2(S)$ \\
\hline KNKp & 6.25 & 6.25 & $<2(S)$ \\
\hline КРCKp1 & 50 & 6.25 & $8(\mathrm{R})$ \\
\hline КРСКp3 & 100 & 25 & $<2(S)$ \\
\hline КРСKp4 & 25 & 25 & $<2(S)$ \\
\hline КРСКp5 & 50 & 12.5 & $<2(S)$ \\
\hline КРСКр6 & 12.5 & 12.5 & $<2(\mathrm{~S})$ \\
\hline КРСКp7 & 12.5 & 12.5 & $<2(\mathrm{~S})$ \\
\hline КРCKp 8 & 50 & 12.5 & $<2(S)$ \\
\hline КРСK $p 9$ & 12.5 & 12.5 & $<2(S)$ \\
\hline КРСКp10 & 50 & 12.5 & $<2(S)$ \\
\hline КРСК $p 11$ & 25 & 12.5 & $<2(S)$ \\
\hline КРСКp12 & 25 & 25 & $<2(S)$ \\
\hline КРСК 13 & 25 & 12.5 & $<2(S)$ \\
\hline КРСК $p 15$ & 50 & 25 & $8(\mathrm{R})$ \\
\hline КРСКp16 & 25 & 25 & $<2(S)$ \\
\hline КРСК $p 17$ & 25 & 12.5 & $<2(\mathrm{~S})$ \\
\hline КРСКp18 & 25 & 12.5 & $<2(S)$ \\
\hline VIMKp & 50 & 25 & $<2(S)$ \\
\hline NDMK $p 1$ & 25 & 25 & $<2(S)$ \\
\hline NDMK $p 2$ & 50 & 25 & $<2(S)$ \\
\hline NDMKp3 & 100 & 25 & $<2(S)$ \\
\hline
\end{tabular}

Polymyxin E used as control conventional antimicrobial.

\section{Discussion}

Klebsiella pneumoniae is a frequent colonizer of the human gut and a major cause of healthcare-related infections whose treatment is complicated by the constant increase in antibiotic resistance. K. pneumoniae was included in the "ESKAPE" group (Enterococcus faecium, Staphylococcus aureus, K. pneumoniae, Acinetobacter baumannii, Pseudomonas aeruginosa and Enterobacter species) [18]. These pathogens acquired resistances through time, becoming one of the major health concerns of the modern day.

Carbapenems represent the last-resort beta-lactams, and carbapenem-resistant $K$. pneumoniae strains are currently spread all over the world [8]. The most relevant mechanism of carbapenem resistance is the production of carbapenemases. Klebsiella pneumoniae carbapenemases (KPCs) are the most common enzymes reported worldwide and capable of deactivating all of the beta-lactams [20]. Among the metallo-beta-lactamases (MBL), New Delhi MBL (NDM), Verona integron-encoded MBL (VIM) and imipenemase MBL (IMP) are the most common enzymes identified worldwide [8]. MBL-producers are continuously isolated in new regions, notably K. pneumoniae strains harboring the $n d m$ gene [21]. 
The worrying spread of carbapenemase-producing enterobacteria is due to the prevalent localization of these genes on mobile genetic elements. K. pneumoniae can both acquire and carry a great number of genetic mobile elements, thus accumulating resistance genes and expanding its accessory genome, with the evolution of multi drug- and extensively drug-resistant strains [22].

Most of the recently approved drugs for the treatment of CRE are new combinations of an old beta-lactam with a second-generation beta-lactam inhibitor (BL/BLI). These combinations are ineffective on MBL-producing strains, whereas they generally show activity on strains harboring KPC carbapenemases [23]. Among these new combinations, ceftazidime/avibactam was approved by the FDA in 2015. Although it was recently introduced, KPC-producing K. pneumoniae isolates resistant to ceftazidime/avibactam have already been reported [24,25].

For that reason, the attention shifted on the identification of natural-derived peptides, whose mechanisms of action strongly differ from the classic antibiotics.

Among the novel generations of antimicrobial compounds, the antimicrobial peptides (AMPs) play a significant role in this context [26,27]. AMPs are widely produced by different kinds of living forms, and their structure typically consist of a variable-length amino acids chain (10 to 60 a.a.) $[28,29]$. The positive charge due to the presence of basic residues (lys and arg), the hydrophobic residues (about 50\%) and the amphipathic nature are commonly shared features that characterize those molecules [30]. Considering that the bacterial membrane has been identified as a physical target of AMPs [31], the development of resistance mechanisms is greatly hampered. On the other hand, the cellular toxicity and the pharmacokinetic issues represent the main drawbacks of these compounds [32]. To augment their activity against bacteria and decrease the cytotoxicity, lipidation strategy was employed [19].

In our previous study, two derivatives of the Temporin L from Rana temporaria, named 1B and C, were tested on Pseudomonas aeruginosa, Klebsiella pneumoniae and Staphylococcus aureus, showing good activity on these pathogens. Based on these preliminary results, in this study the peptides 1B and C were evaluated on 20 clinical strains of K. pneumoniae, all carbapenemase-producers. Of these, 16 strains carried a KPC carbapenemase, whereas four isolates harbored an MBL. Initially, 18 KPC-producing clinical strains were included in the study, all from the intensive care unit. They were genotyped by RAPD: most of the tested strains showed different RAPD profiles, confirming the high heterogeneity of K. pneumoniae [33]. For those strains showing comparable RAPD profiles, antibiotic-susceptibility patterns were considered. On this basis, strains 2 and 14 were excluded as both RAPD and antibiotic-susceptibility profiles were comparable to strains 1 and 13, respectively. K. pneumoniae strains with comparable RAPD profile, but with different antibiotic-susceptibility pattern for at least one interpretative category were instead included in the study.

Peptides 1B and $\mathbf{C}$ showed activity on all the tested strains. The lipidated analogue $\mathbf{C}$ was more active than peptide 1B, probably due to the modification applied on its molecular structure, with MIC values ranging from 6.25 to $25 \mu \mathrm{M}$ against the KPC-producing strains, and MIC values of $25 \mu \mathrm{M}$ against the MBL-producing strains. Interestingly, at the highest concentration of $25 \mu \mathrm{M}$ used in this study, it has previously been shown that peptide $\mathrm{C}$ was not cytotoxic both on human keratinocytes and erythrocytes [19]. MBL producers are very difficult to treat as therapeutic options are even more limited, but isolation of KPC-producing strains resistant to the new BL/BLI combinations complicates antibiotic treatment. In our study, 2 (KPCKp8 and KPCKp15) of the 16 KPC-producers were resistant to ceftazidime/avibactam. Moreover, these results seem particularly interesting to us as all the carbapenemase-producing strains tested were also resistant to classes of antibiotics other than beta-lactams. Notably, KPCKp1 strain was also resistant to polymyxin E, drug shelved for its side effects and then reintroduced into human therapy as a salvage treatment against multidrug-resistant Gram-negative bacteria [34]; the KPCKp15 strain was resistant to all drugs used. 


\section{Materials and Methods}

\subsection{Synthesis}

The peptides 1B [H-Phe-Val-Pro-Trp-Phe-Ser-Lys-Phe-DLeu-DLys-Arg-Ile-Leu-NH $\mathrm{NH}_{2}$ and $\mathrm{C}$ [H-Phe(4-NHCO $\left.\left(\mathrm{CH}_{2}\right)_{3} \mathrm{CH}_{3}\right)$-Val-Pro-Trp-Phe-Ser-Lys-Phe-DLeu-DLys-Arg-Ile-Leu$\mathrm{NH}_{2}$ ] were synthesized using Fmoc-based ultrasonic-assisted solid phase peptide synthesis (US-SPPS) methodology [35]. The elongation of the peptide sequence consisted in repeated cycles of Fmoc-deprotection and coupling reactions. Specifically, the Fmoc group was removed treating the resin with a solution of $20 \%$ piperidine in DMF $(0.5 \times 1 \mathrm{~min})$ by ultrasonic irradiations, whereas each coupling reaction was performed using $\mathrm{N}^{\alpha}$-Fmocamino acid ( 3 equiv), HBTU ( 3 equiv), HOBt ( 3 equiv) and DIEA ( 6 equiv) in DMF for 5 min by ultrasound waves. After the peptide assembly, the conjugation of valeric acid in para position of $\mathrm{Phe}^{1}$ of peptide $\mathrm{C}$ was performed as previously reported [19]. In particular, the nitro group in para position of $\mathrm{Phe}^{1}$ was reduced treating the resin with a $1 \mathrm{M}$ solution of $\mathrm{SnCl}_{2}$ in DMF for $12 \mathrm{~h}$ and then, the valeric acid (3 equiv) was added using HBTU (3 equiv), HOBt ( 3 equiv) and DIEA (6 equiv) in DMF for $2 \mathrm{~h}$ on automated shaker. Finally, peptides were treated with a cleavage cocktail (TFA:TIS: $\left.\mathrm{H}_{2} \mathrm{O}, 95: 2.5: 2.5\right)$ to be released from the resin and cleaved from their protecting groups, and then they were purified and characterized by RP-HPLC using linear gradients of MeCN (0.1\% TFA) in water ( $0.1 \%$ TFA), from 10 to $90 \%$ over $20 \mathrm{~min}$.

\subsection{Bacterial Strains and Culture Conditions}

Strains of Klebsiella pneumoniae evaluated in this study included reference strains such as carbapeneme-susceptible ATCC 13883 (KCQ) and carbapeneme-resistant ATCC BAA-1705 (KAT), and 23 clinical strains (Table 1) belonging to a collection of anonymous isolates, previously established at the Department of Molecular Medicine and Medical Biotechnology (University of Naples Federico II) during two-year period (March 2020 March 2021). Among the clinical strains, the first 19 listed strains all come from the Intensive Care Unit and all but one $(\mathrm{KNKp})$ were resistant to carbapenems. The last 4 listed strains were from different wards (Cystic Fibrosis Center, Oncology, Geriatrics, Cardiac Surgery) and were metallo- $\beta$-lactamases (MBLs) producers. Identification was performed by biochemical characterization using the Vitek II system (BioMérieux, Marcy-l'Étoile, France) and was confirmed by MS MALDI-TOF (Bruker Daltonics, Bremen, Germany). Antibiotic susceptibility profiles were assessed using automated systems (Vitek 2; PhoenixBecton Dickinson, Sparks, NV, USA) and broth microdilution method. Carbapenemase gene detection was performed using the Xpert Carba-R-test (Cepheid, Sunnyvale, CA, USA), real-time PCR diagnostic tests that allow to detect and differentiate the most prevalent carbapenemase gene families. All strains were stored as $15 \%(v / v)$ glycerol stocks at $-80{ }^{\circ} \mathrm{C}$. Before each experiment, cells were sub-cultured from stocks on Tryptic Soy Agar (TSA) (Becton Dickinson) plates to $37^{\circ} \mathrm{C}$ for $24 \mathrm{~h}$.

\subsection{Antimicrobial Assays: Determination of the Minimum Inhibitory Concentration (MIC) and the Minimum Bactericidal Concentration (MBC)}

The antibacterial activity of peptides $\mathbf{1 B}$ and $\mathbf{C}$ was determined using a standard method of microdilution in broth, following the procedure already described [36]. For each strain, the bacterial suspension was prepared at $0.5 \mathrm{McFarland}$ standard (corresponding to about $10^{8} \mathrm{CFU} / \mathrm{mL}$ ) in Mueller Hinton broth (MHB-Becton Dickinson) and subsequently adjusted to about $1.5 \times 10^{6} \mathrm{CFU} / \mathrm{mL}$. One hundred microliter aliquots of this suspension were dispensed into 96-well microtiter plates. A 2x stock solution of temporin was serially diluted (twofold dilutions) with MHB and added to the wells to a final concentration between $3.125 \mu \mathrm{M}$ and $100 \mu \mathrm{M}$. The plates were incubated at $37^{\circ} \mathrm{C}$ for $19 \mathrm{~h}$ with stirring (300 rpm). The turbidity of the medium was measured with a spectrophotometer at $595 \mathrm{~nm}$ (Bio-Rad Laboratories S.r.l., Hercules, CA, USA). Wells with only MHB were used as a negative control and wells without peptide as a growth control. Polymyxin E (SigmaAldrich, Milan, Italy) was selected as a control from the conventional antimicrobials and 
tested at concentrations ranging from $2 \mu \mathrm{g} / \mathrm{mL}$ to $8 \mu \mathrm{g} / \mathrm{mL}$. The MIC was defined as the lowest concentration of the compound that resulted in $100 \%$ growth inhibition after $19 \mathrm{~h}$ of incubation. The MBC was determined by transferring $50 \mu \mathrm{L}$ aliquots of each well with concentrations equal to or higher than the MIC, onto TSA plates and incubating the plates at $37^{\circ} \mathrm{C}$ for $24 \mathrm{~h}$. The lowest compound concentration that yielded no bacterial growth on agar plates was defined as the MBC. Each compound was tested alone in triplicate; each experiment was performed twice.

\subsection{RAPD Analysis}

Random Amplification of Polymorphic DNA was performed on both ATCC strains and clinical isolates. Among all the tested primer, the HI-RP (5'-AACTCGGCGACCAGC TACAA-3') primer was selected and used for the amplification [15]. The final RAPD conditions for HI-RP were: $0.5 \mu \mathrm{L}$ of genomic DNA, $20 \mu \mathrm{L} \mathrm{H}_{2} \mathrm{O}, 2.5 \mu \mathrm{L}$ buffer, $1 \mu \mathrm{L}$ dNTP, $1 \mu \mathrm{L}$ primers and $0.1 \mu \mathrm{L}$ of Taq DNA polymerase (Biotech Rabbit) in a final volume of $25 \mu \mathrm{L}$. The amplification program included an initial step at $94{ }^{\circ} \mathrm{C}$ for $5 \mathrm{~min}$, followed by 40 cycles of $30 \mathrm{~s}$ at $95^{\circ} \mathrm{C}, 1 \mathrm{~min}$ at $36^{\circ} \mathrm{C}$, and $1 \mathrm{~min}$ at $72{ }^{\circ} \mathrm{C}$, with a final extension cycle at $72{ }^{\circ} \mathrm{C}$ for $7 \mathrm{~min}$. Reactions were performed using a thermo cycler (T100 THERMAL CYCLER-BioRad, Hercules, CA, USA). The PCR products were analysed by electrophoresis on $2 \%$ agarose gel in TBE and stained with ethidium bromide. The gels were photographed under UV light to record the results.

\section{Conclusions}

In conclusion, the obtained data show that the selected lipidated peptide $C$ seems very promising for the development of a new drug with extensive antimicrobial activity and confirm and underline the potential role of temporins, and AMPs globally and efficiently counter the outbreaks of new multidrug-resistant pathogens. These compounds represent a valid mean to support both the management of serious infections and contrast the further expansion of antibiotic resistances.

Author Contributions: R.B. and F.M. performed peptide synthesis. E.R., N.M. and E.B. performed the experiments. R.P. isolated and identified the clinical strains. M.R.C., P.G. and E.B. designed the study, drafted and wrote the manuscript. M.R.C. and E.B. edited and revised the manuscript. All authors have read and agreed to the published version of the manuscript.

Funding: This research did not receive any specific grant from funding agencies in the public, commercial, or not-for-profit sectors.

Data Availability Statement: Data are contained within the manuscript.

Conflicts of Interest: The authors declare no conflict of interest.

\section{References}

1. Vading, M.; Nauclér, P.; Kalin, M.; Giske, C.G. Invasive infection caused by Klebsiella pneumoniae is a disease affecting patients with high comorbidity and associated with high long-term mortality. PLoS ONE 2018, 13, e0195258. [CrossRef]

2. Vardakas, K.Z.; Tansarli, G.S.; Rafailidis, P.I.; Falagas, M.E. Carbapenems versus alternative antibiotics for the treatment of bacteraemia due to Enterobacteriaceae producing extended-spectrum $\beta$-lactamases: A systematic review and meta-analysis. J. Antimicrob. Chemother. 2012, 67, 2793-2803. [CrossRef]

3. Walsh, T.R. Emerging carbapenemases: A global perspective. Int. J. Antimicrob. Agents 2010, 36, 8-14. [CrossRef]

4. Pitout, J.D.D.; Nordmann, P.; Poirel, L. Carbapenemase-Producing Klebsiella pneumoniae, a Key Pathogen Set for Global Nosocomial Dominance. Antimicrob. Agents Chemother. 2015, 59, 5873-5884. [CrossRef] [PubMed]

5. Cui, X.; Zhang, H.; Du, H. Carbapenemases in Enterobacteriaceae: Detection and Antimicrobial Therapy. Front. Microbiol. 2019, 10, 1823. [CrossRef]

6. Logan, L.K.; Weinstein, R.A. The Epidemiology of Carbapenem-Resistant Enterobacteriaceae: The Impact and Evolution of a Global Menace. J. Infect. Dis. 2017, 215 (Suppl. 1), S28-S36. [CrossRef]

7. Ambler, R.P. The structure of beta-lactamases. Philos. Trans. R. Soc. Lond. B Biol. Sci. 1980, 289, 321-331.

8. Bonomo, R.A.; Burd, E.M.; Conly, J.; Limbago, B.M.; Poirel, L.; Segre, J.L.; Westblade, L.F. Carbapenemase-Producing Organisms: A Global Scourge. Clin. Infect. Dis. 2018, 66, 1290-1297. [CrossRef] 
9. Trecarichi, E.M.; Tumbarello, M. Therapeutic options for carbapenem-resistant Enterobacteriaceae infections. Virulence 2017, 8, 470-484. [CrossRef]

10. WHO. Global Priority List of Antibiotic-Resistant Bacteria to Guide Research, Discovery, and Development of New Antibiotics. World Health Organization, 2017. Available online: https:/ /www.who.int/medicines/publications/WHO-PPL-Short_Summary_ 25Feb-ET_NM_WHO.pdf (accessed on 3 August 2021).

11. Bassetti, M.; Vena, A.; Sepulcri, C.; Giacobbe, D.R.; Peghin, M. Treatment of Bloodstream Infections Due to Gram-Negative Bacteria with Difficult-to-Treat Resistance. Antibiotics 2020, 9, 632. [CrossRef] [PubMed]

12. Mangoni, M.L.; Grazia, A.D.; Cappiello, F.; Casciaro, B.; Luca, V. Naturally occurring peptides from Rana temporaria: Antimicrobial properties and more. Curr. Top. Med. Chem. 2016, 16, 54-64. [CrossRef]

13. Rinaldi, A.C.; Mangoni, M.L.; Rufo, A.; Luzi, C.; Barra, D.; Zhao, H.; Kinnunen, P.K.; Bozzi, A.; Di Giulio, A.; Simmaco, M. Temporin L: Antimicrobial, haemolytic and cytotoxic activities, and effects on membrane permeabilization in lipid vesicles. Biochem. J. 2002, 368, 91-100. [CrossRef]

14. Merlino, F.; Carotenuto, A.; Casciaro, B.; Martora, F.; Loffredo, M.R.; Di Grazia, A.; Yousif, A.M.; Brancaccio, D.; Palomba, L.; Novellino, E.; et al. Glycine-replaced derivatives of [Pro(3),DLeu(9)]TL, a temporin L analogue: Evaluation of antimicrobial, cytotoxic and hemolytic activities. Eur. J. Med. Chem. 2017, 139, 750-761. [CrossRef] [PubMed]

15. Bellavita, R.; Casciaro, B.; Di Maro, S.; Brancaccio, D.; Carotenuto, A.; Falanga, A.; Cappiello, F.; Buommino, E.; Galdiero, S.; Novellino, E.; et al. First-in-class cyclic Temporin L analogue: Design, synthesis, and antimicrobial assessment. J. Med. Chem. 2021, 64, 11675-11694. [CrossRef] [PubMed]

16. Buommino, E.; Carotenuto, A.; Antignano, I.; Bellavita, R.; Casciaro, B.; Loffredo, M.R.; Merlino, F.; Novellino, E.; Mangoni, M.L.; Nocera, F.P.; et al. The outcomes of decorated prolines in the discovery of antimicrobial peptides from Temporin-L. Chem. Med. Chem. 2019, 14, 1283-1290. [CrossRef] [PubMed]

17. Bellavita, R.; Vollaro, A.; Catania, M.R.; Merlino, F.; De Martino, L.; Nocera, F.P.; DellaGreca, M.; Lembo, F.; Grieco, P.; Buommino, E. Novel antimicrobial peptide from Temporin $\mathrm{L}$ in the treatment of Staphylococcus pseudintermedius and Malassezia pachydermatis in polymicrobial inter-kingdom infection. Antibiotics 2020, 9, 530. [CrossRef]

18. Bellavita, R.; Raucci, F.; Merlino, F.; Piccolo, M.; Ferraro, M.G.; Irace, C.; Santamaria, R.; Iqbal, A.J.; Novellino, E.; Grieco, P.; et al. Temporin L-derived peptide as a regulator of the acute inflammatory response in zymosan-induced peritonitis. Biomed. Pharmacother. 2020, 123, 109788. [CrossRef]

19. Bellavita, R.; Falanga, A.; Buommino, E.; Merlino, F.; Casciaro, B.; Cappiello, F.; Mangoni, M.L.; Novellino, E.; Catania, M.R.; Paolillo, R.; et al. Novel temporin L antimicrobial peptides: Promoting self-assembling by lipidic tags to tackle superbugs. J. Enzym Inhib. Med. Chem. 2020, 35, 1751-1764. [CrossRef]

20. Plazak, M.E.; Tamma, P.D.; Heil, E.L. The antibiotic arms race: Current and emerging therapy for Klebsiella pneumoniae carbapenemase (KPC)_Producing bacteria. Expert. Opin. Pharmacother. 2018, 19, 2019-2031. [CrossRef]

21. Lee, C.R.; Lee, J.H.; Park, K.S.; Kim, Y.B.; Jeong, B.C.; Lee, S.H. Global Dissemination of Carbapenemase-Producing Klebsiella pneumoniae: Epidemiology, Genetic Context, Treatment Options, and Detection Methods. Front. Microbiol. 2016, 7, 895. [CrossRef]

22. Navon-Venezia, S.; Kondratyeva, K.; Carattoli, A. Klebsiella pneumoniae: A major worldwide source and shuttle for antibiotic resistance. FEMS Microbiol. Rev. 2017, 41, 252-275. [CrossRef]

23. Yusuf, E.; Bax, H.I.; Verkaik, N.J.; van Westreenen, M. An Update on Eight "New" Antibiotics against Multidrug-Resistant Gram-Negative Bacteria. J. Clin. Med. 2021, 10, 1068. [CrossRef]

24. Göttig, S.; Frank, D.; Mungo, E.; Nolte, A.; Hogardt, M.; Besier, S.; Wichelhaus, T.A. Emergence of ceftazidime/avibactam resistance in KPC-3-producing Klebsiella pneumoniae in vivo. J. Antimicrob. Chemother. 2019, 74, 3211-3216. [CrossRef]

25. Gaibani, P.; Re, M.C.; Campoli, C.; Viale, P.L.; Ambretti, S. Bloodstream infection caused by KPC-producing Klebsiella pneumoniae resistant to ceftazidime/avibactam: Epidemiology and genomic characterization. Clin. Microbiol. Infect. 2020, 26, 516.e1-516.e4. [CrossRef]

26. Wang, J.; Dou, X.; Song, J.; Lyu, Y.; Zhu, X.; Xu, L.; Li, W.; Shan, A. Antimicrobial peptides: Promising alternatives in the post feeding antibiotic era. Med. Res. Rev. 2019, 39, 831-859. [CrossRef] [PubMed]

27. Falanga, A.; Galdiero, M.; Galdiero, S. Membranotropic cell penetrating peptides: The outstanding journey. Int. J. Mol. Sci. 2015, 16, 25323-25337. [CrossRef]

28. Kumar, P.; Kizhakkedathu, J.N.; Straus, S.K. Antimicrobial peptides: Diversity, mechanism of action and strategies to improve the activity and biocompatibility in vivo. Biomolecules 2018, 8, 4. [CrossRef]

29. Falanga, A.; Lombardi, L.; Franci, G.; Vitiello, M.; Iovene, M.R.; Morelli, G.; Galdiero, M.; Galdiero, S. Marine antimicrobial peptides: Nature provides templates for the design of novel compounds against pathogenic bacteria. Int. J. Mol. Sci. 2016, 17, 785. [CrossRef] [PubMed]

30. Hollmann, A.; Martinez, M.; Maturana, P.; Semorile, L.C.; Maffia, P.C. Antimicrobial peptides: Interaction with model and biological membranes and synergism with chemical antibiotics. Front. Chem. 2018, 6, 204. [CrossRef] [PubMed]

31. Bechinger, B.; Gorr, S.U. Antimicrobial Peptides: Mechanisms of Action and Resistance. J. Dent. Res. 2017, 96, 254-260. [CrossRef]

32. Zharkova, M.S.; Orlov, D.S.; Golubeva, O.Y.; Chakchir, O.B.; Eliseev, I.E.; Grinchuk, T.M.; Shamova, O.V. Application of antimicrobial peptides of the innate immune system in combination with conventional antibiotics-a novel way to combat antibiotic resistance? Front. Cell. Infect. Microbiol. 2019, 9, 128. [CrossRef] [PubMed] 
33. Wasfi, R.; Elkhatib, W.F.; Ashour, H.M. Molecular typing and virulence analysis of multidrug resistant Klebsiella pneumoniae clinical isolates recovered from Egyptian hospitals. Sci. Rep. 2016, 6, 38929. [CrossRef]

34. Boisson, M.; Gregoire, N.; Couet, W.; Mimoz, O. Colistin in critically ill patients. Minerva Anestesiol. 2013, 79, 200-208. [PubMed]

35. Merlino, F.; Tomassi, S.; Yousif, A.M.; Messere, A.; Marinelli, L.; Grieco, P.; Novellino, E.; Cosconati, S.; Di Maro, S. Boosting Fmoc solid-phase peptide synthesis by ultrasonication. Org. Lett. 2019, 21, 6378-6382. [CrossRef] [PubMed]

36. Roscetto, E.; Masi, M.; Esposito, M.; Di Lecce, R.; Delicato, A.; Maddau, L.; Calabrò, V.; Evidente, A.; Catania, M.R. Anti-Biofilm Activity of the Fungal Phytotoxin Sphaeropsidin A Against Clinical Isolates of Antibiotic-Resistant Bacteria. Toxins 2020, $12,444$. [CrossRef] [PubMed] 